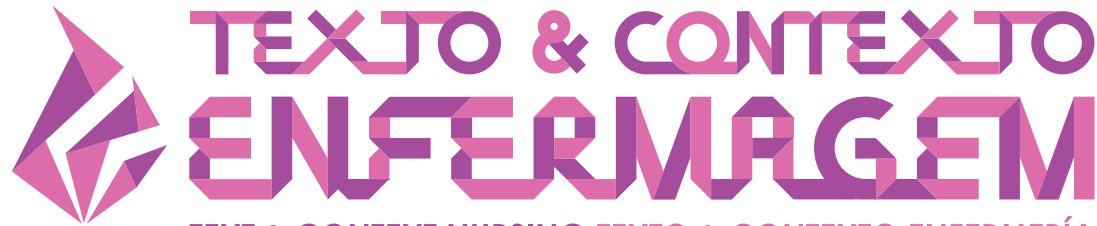

TEXT \& CONTEXT NURSING TEXTO \& CONTEXTO ENFERMERÍA

\section{MENTAL ILLNESS IN THE GENERAL POPULATION AND HEALTH PROFESSIONALS DURING COVID-19: A SCOPING REVIEW}

\author{
Wanderson Carneiro Moreira ${ }^{1}$ (D) \\ Anderson Reis de Sousa ${ }^{2}$ (i) \\ Maria do Perpétuo Socorro de Sousa Nóbrega ${ }^{1}$ (i)
}

1Universidade de São Paulo, Escola de Enfermagem, Programa de Pós-Graduação em Enfermagem. São Paulo, São Paulo, Brasil. 2Universidade Federal da Bahia, Escola de Enfermagem, Programa de Pós-Graduação em Enfermagem. Salvador, Bahia, Brasil.

\begin{abstract}
Objective: to map the literature on mental illness in the general population and in health professionals during the Covid-19 pandemic.

Method: scoping review in the MEDLINE/PubMed, SCOPUS, Web of Science, PsycINFO, Science Direct databases and in the medRxiv, bioRxiv and PsyArXiv preprint servers, using the descriptors "Covid-19", "coronavirus infection", "coronavirus", "2019-nCoV", "2019 new coronavirus disease", "SARS-CoV-2", "health personnel", "general public" and "mental health".

Results: 1,168 articles were found, among which 27 were analyzed. $19(70 \%)$ dealt with the prevalence of mental illness in the general population, six $(22 \%)$ in doctors and nurses, one $(4 \%)$ in other health professionals and one $(4 \%)$ in the general population and nurses. 19 symptoms of mental illness were identified.

Conclusion: the Covid-19 pandemic triggered anxiety, depression, stress and post-traumatic stress disorders in the general population and health professionals more often. Women, students and nurses are among the most affected.
\end{abstract}

DESCRIPTORS: Covid-19. Coronavirus infections. Pandemics. Mental health. Psychological stress. 


\section{ADOECIMENTO MENTAL NA POPULAÇÃO GERAL E EM PROFISSIONAIS DE SAÚDE DURANTE A COVID-19: SCOPING REVIEW}

\section{RESUMO}

Objetivo: mapear a literatura sobre adoecimento mental na população geral e em profissionais de saúde durante a pandemia da Covid-19.

Método: scoping review nas bases de dados MEDLINE/PubMed, SCOPUS, Web of Science, PsycINFO, Science Direct e nos servidores de preprints medRxiv, bioRxiv e PsyArXiv, usando os descritores "Covid-19", "coronavirus infection", "coronavirus", "2019-nCoV", "2019 novel coronavirus disease", "SARS-CoV-2", "health personnel", "general public" e "mental health".

Resultados: foram encontrados 1.168 artigos, dos quais 27 foram analisados. 19 (70\%) versaram sobre a prevalência de adoecimento mental na população geral, seis (22\%) em médicos e enfermeiros, um (4\%) nos demais profissionais de saúde e um (4\%) na população geral e enfermeiros. Identificaram-se 19 sintomas de adoecimento mental.

Conclusão: a pandemia da Covid-19 desencadeou, com maior frequência, ansiedade, depressão, estresse e transtornos do estresse pós-traumático na população geral e em profissionais de saúde. Mulheres, estudantes e enfermeiros estão entre os mais acometidos.

DESCRITORES: Covid-19. Infecções por coronavírus. Pandemias. Saúde mental. Estresse psicológico.

\section{ENFERMEDAD MENTAL EN LA POBLACIÓN GENERAL Y EN LOS PROFESIONALES DE SALUD DURANTE COVID-19: EXAMEN DE ALCANCE}

\section{RESUMEN}

Objetivo: mapear la literatura sobre enfermedades mentales en la población general y en profesionales de la salud durante la pandemia de Covid-19.

Método: scoping review en las bases de datos MEDLINE/PubMed, SCOPUS, Web of Science, PsycINFO, Science Direct y en servidores de preprints medRxiv, bioRxiv y PsyArXiv, usando los descriptores "Covid-19", "coronavirus infection", "coronavirus", "2019-nCoV", "2019 novel coronavirus disease", "SARS-CoV-2", "health personnel", "general public" e "mental health".

Resultados: se encontraron 1.168 artículos, de los cuales 27 fueron analizados. 19 (70\%) se ocuparon de la prevalencia de enfermedades mentales en la población general, seis $(22 \%)$ en médicos y enfermeras, uno $(4 \%)$ en otros profesionales de la salud y uno (4\%) en la población general y los enfermeros. Se identificaron 19 síntomas de enfermedad mental.

Conclusión: la pandemia de Covid-19 desencadenó ansiedad, depresión, estrés y trastornos de estrés postraumático con mayor frecuencia en la población general y los profesionales de la salud. Las mujeres, los estudiantes y las enfermeras se encuentran entre los más afectados.

DESCRIPTORES: Covid-19. Infecciones por coronavirus. Pandemias Salud mental. Estrés psicológico. 


\section{INTRODUCTION}

In December 2019, China registered a new pneumonia, known as Covid-19 (Coronavirus Disease-2019), whose causative virus was named SARS-CoV-2 (Severe Acute Respiratory Syndrome Coronavirus 2). ${ }^{1}$ This virus is highly transmissible and has spread rapidly throughout the world, leading the World Health Organization (WHO) ${ }^{2}$ to declare a pandemic in March 2020, which required all countries to implement emergency public health measures of international interest.

Although some of the physical signs and symptoms of this disease are known, ${ }^{3}$ these have not yet been sufficiently understood or systematized and, to date, there is no defined and proven effective treatment. ${ }^{4}$ Due to the worldwide outbreak of SARS-CoV-2 infection , quarantine, social distancing and isolation measures were suggested as a way to prevent the spread of Covid-19. ${ }^{4}$ However, such control measures, associated with false information, also called fake news and/or pseudo-information, and the absence of effective treatment contributed to insecurity, panic and fear, directly affecting the daily life and mental health of the population and health professionals. ${ }^{5}$

During outbreaks of infectious diseases, damage to mental health tends to be neglected in comparison to biological risk and treatment measures. ${ }^{5}$ However, they can affect a greater number of people and remain even after epidemics end. ${ }^{5-6}$ However, such psychological impacts can be minimized and even avoided through mental health and psychiatric care. ${ }^{7}$ The need for this care was evidenced in previous epidemiological crises ${ }^{8}$ and is now reinforced in the context of Covid-19. ${ }^{9-10}$

In previous epidemics, such as the Middle East Respiratory Syndrome (MERS), studies show that feelings such as anxiety and anger were triggered in the population and remained for up to six months after the outbreak ended. ${ }^{11-12}$ In Saudi Arabia and South Korea, health professionals who worked on the frontline of care reported fear, nervousness ${ }^{13}$ and stress. ${ }^{14}$

Recently, studies on the mental health of the general population and health professionals working on the frontline have been published. However, evidencing this process in a literature review is relevant, as it offers support for the development of actions and focal public policies aimed at the community and health teams. In this context, the objective of this study is to map the literature on mental illness in the general population and in health professionals during the Covid-19 pandemic.

\section{METHODS}

It is a systematic scoping review, which followed the recommendations of the Joanna Briggs Institute $(\mathrm{JBI}){ }^{15}$ For the formulation of the research question, the PCC strategy was used, an acronym for "population" $(\mathrm{P})$, " concept "(C) and" context "(C): what symptoms of mental illness are present in the general population and in health professionals in the context of the Covid-19 pandemic?

For inclusion in this review, studies should be primary, published in any language and discuss mental illness in the general population and in health professionals in the context of the Covid-19 pandemic.

The search strategies were built in three stages. Initially, "Covid-19" AND "Mental health" was used in the Medical Literature Analysis AND Retrieval System Online via the US National Library of Medicine (MEDLINE / PubMed) to find uncontrolled descriptors contained in the articles of interest. Then, combinations of controlled descriptors were obtained, obtained from Medical Subject Headings (MeSH), and uncontrolled, obtained in the initial search, plus the Boolean operators "OR" and "AND". Finally, this strategy was adapted for each database (Table 1). 
Table 1 - Search strategies used by databases. São Paulo, SP, Brasil, 2020.

\begin{tabular}{|c|c|c|}
\hline Database & Search strategy & Results \\
\hline MEDLINE/PubMed & (“covid 19") AND (“mental health”) & 320 \\
\hline MEDLINE/PubMed & & 351 \\
\hline PsyclNFO & ("coronavirus infection" OR "coronavirus" OR "2019-nCoV" OR & 49 \\
\hline SCOPUS & "2019 novel coronavirus disease” OR “COVID-19” OR & 239 \\
\hline Web of Science & & 65 \\
\hline Science Direct & $\begin{array}{c}\text { ("coronavirus infection" OR "coronavirus" OR "2019-nCoV" OR } \\
\text { "2019 novel coronavirus disease" OR "COVID-19" } \\
\text { OR "SARS-CoV-2") AND (Mental health) AND } \\
\text { ("General public" OR "Health Personnel") }\end{array}$ & 119 \\
\hline
\end{tabular}

The search and study selection took place between the months of March and May 2020 and were carried out by two independent reviewers, with the differences being resolved by a third reviewer. The databases MEDLINE/PubMed, American Psychological Association (PsycINFO), SCOPUS (Elsevier), Science Direct (Elsevier), Web of Science (WOS) and the preprint servers medRxiv, bioRxiv and PsyArXiv were selected.

The studies found were exported to the EndNote $®$ reference manager software in order to identify duplicates and gather all publications. In addition, the reference lists was consulted in order to find additional studies. The study selection followed the recommendations of the Preferred Reporting Items for Systematic reviews and Meta-Analyzes extension for Scoping Reviews (PRISMA-ScR), ${ }^{16}$ Figure 1.

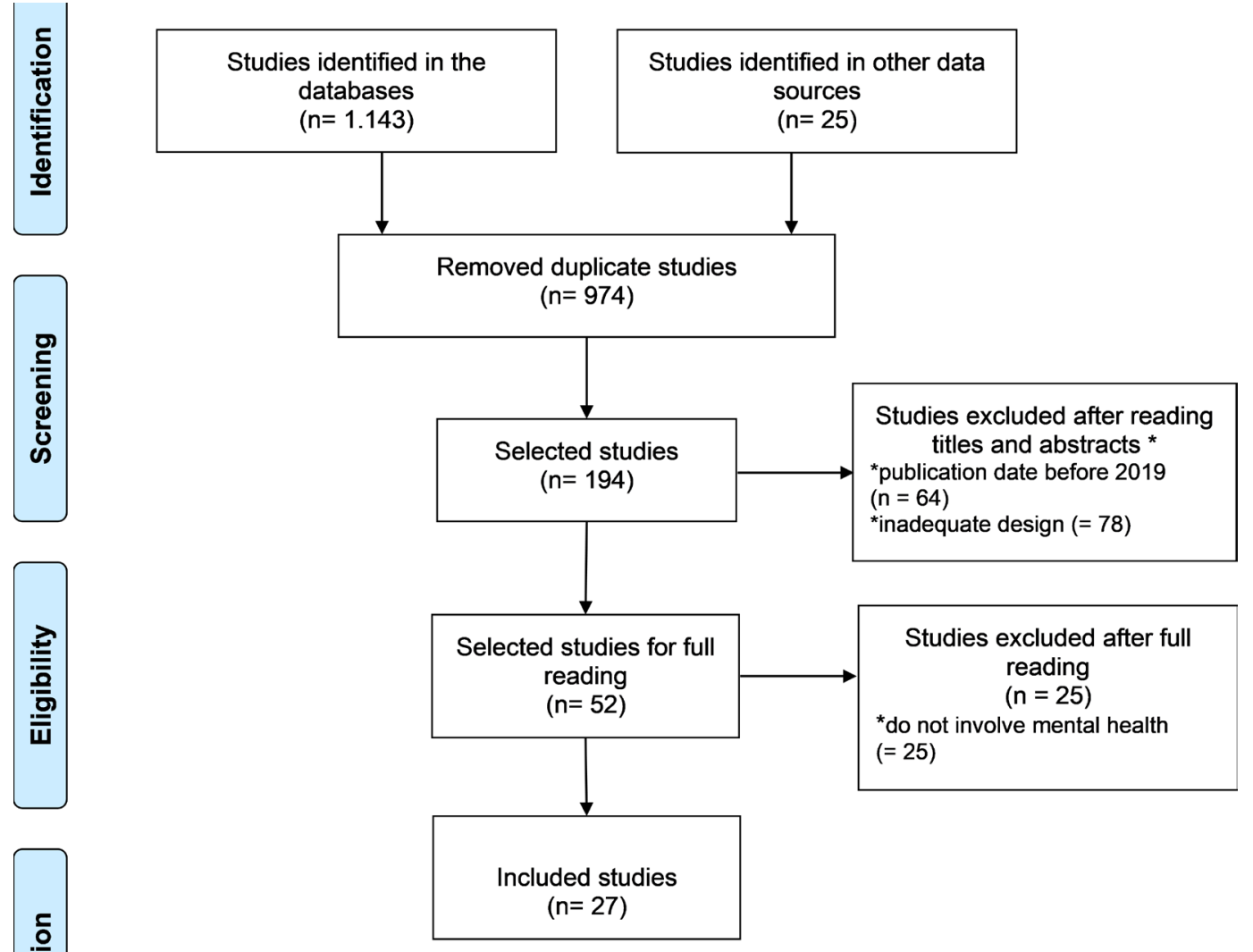

Figure 1 - Flowchart of study selection. São Paulo, SP, Brazil, 2020. 
A data collection instrument validated by Ursi ${ }^{17}$ and adapted for this study was chosen for data analysis and extraction. It is noteworthy that the scope reviews do not foresee the exclusion of articles according to criteria of methodological quality criteria, therefore, no article was excluded based on this criterion. ${ }^{18}$ In addition, the protocol of this review was previously assessed by experts in the method in question.

After evaluating the texts in full, a descriptive analysis of the evidenced results was carried out, in which the summary of each study included in the review was presented, as well as the comparisons between the surveys.

\section{RESULTS}

The 27 selected articles were published in $2020(100 \%),{ }^{19-45}$ by 15 different journals, of which Brain, Behavior, and Immunitycom stood out with five publications (18\%). ${ }^{21-22,27,29}, 45$ Regarding the country of origin, 21 were developed in China (75\%), ${ }^{20,22-32,40-42,44-45}$ two $(7 \%)$ in Italy ${ }^{19,21}$ and the others in Spain, ${ }^{33}$ India, ${ }^{39}$ Iraq $^{43}$ and Turkey ${ }^{30}$ by different researchers and research centers in the areas of Medicine and Nursing.

As for the method adopted in the selected studies, 24 (89\%) have a cross-sectional design ${ }^{19-21,24-39,41-45}$ and the others have a longitudinal design, ${ }^{22}$ case-control ${ }^{40}$ and randomized clinical trial. ${ }^{23}$ As for the sample, ${ }^{19}$ ( $70 \%$ ) investigated the prevalence of illness exclusively in the general population (infected and uninfected); ${ }^{19,21-23,26,28-31,33-35,37,40,42-44}$ six (22\%) exclusively doctors and nurses; ${ }^{24,27,32,36,38,41}$ one $(4 \%)$ doctors, nurses, pharmacists and other professionals; ${ }^{20}$ one $(4 \%)$ general population and nurses. ${ }^{45}$ The sample number ranged from 51 to 17,865 .

Table 2 shows the characterization of the studies included in terms of identification, authors, year of publication, country, journal, methodological design and population / sample.

Table 2 - Shows the characterization of the studies included ( $n=27)$. São Paulo, SP, Brazil. 2020.

\begin{tabular}{|c|c|c|c|c|c|}
\hline References & Authors (ano) & Country & Journal & $\begin{array}{l}\text { Methodological } \\
\text { outline }\end{array}$ & $\begin{array}{l}\text { Population/ } \\
\text { Sample }\end{array}$ \\
\hline $\mathrm{A} 1^{19}$ & Mazza et al. (2020) & Italy & $\begin{array}{l}\text { Int J Environ } \\
\text { Res Public } \\
\text { Health }\end{array}$ & Transversal & $\begin{array}{l}\text { General population } \\
\quad(n=2.766)\end{array}$ \\
\hline $\mathrm{A} 2^{20}$ & Cai et al. (2020) & China & $\begin{array}{l}\text { Asian J } \\
\text { Psychiatr }\end{array}$ & Transversal & $\begin{array}{l}\text { Health Professionals } \\
\qquad(n=1.521)\end{array}$ \\
\hline$A 3^{21}$ & Moccia et al. (2020) & Itália & $\begin{array}{l}\text { Brain, Behav } \\
\text { Immun }\end{array}$ & Transversal & $\begin{array}{l}\text { General population } \\
\qquad(n=500)\end{array}$ \\
\hline $\mathrm{A} 4^{22}$ & Wang et al. (2020) & China & $\begin{array}{l}\text { Brain, Behav } \\
\text { Immun }\end{array}$ & Longitudinal & $\begin{array}{l}\text { General population } \\
\qquad(n=190)\end{array}$ \\
\hline $\mathrm{A} 5^{23}$ & Liu et al. (2020) & China & $\begin{array}{l}\text { Complement } \\
\text { Ther Clin Pract }\end{array}$ & $\begin{array}{l}\text { Randomized } \\
\text { Clinical trial }\end{array}$ & $\begin{array}{c}\text { General population } \\
\qquad(n=51)\end{array}$ \\
\hline$A 6^{24}$ & Lai et al. (2020) & China & $\begin{array}{l}\text { JAMA Netw } \\
\text { Open }\end{array}$ & Transversal & $\begin{array}{l}\text { Doctors and Nurses } \\
\qquad(n=1.257)\end{array}$ \\
\hline$A 7^{25}$ & Huang \& Zhao (2020) & China & Psychiatry Res & Transversal & $\begin{array}{l}\text { General population } \\
\qquad(n=7.236)\end{array}$ \\
\hline$A 8^{26}$ & Wang et al. (2020) & China & $\begin{array}{l}\text { Int J Environ } \\
\text { Res Public } \\
\text { Health }\end{array}$ & Transversal & $\begin{array}{l}\text { General population } \\
\qquad(n=1.210)\end{array}$ \\
\hline
\end{tabular}


Table 2 - Cont.

\begin{tabular}{|c|c|c|c|c|c|}
\hline References & Authors (ano) & Country & Journal & $\begin{array}{l}\text { Methodological } \\
\text { outline }\end{array}$ & $\begin{array}{l}\text { Population/ } \\
\text { Sample }\end{array}$ \\
\hline $\mathrm{A} 9^{27}$ & Kang et al. (2020) & China & $\begin{array}{l}\text { Brain, Behav } \\
\text { Immun }\end{array}$ & Transversal & $\begin{array}{l}\text { Doctors and Nurses } \\
(\mathrm{n}=994)\end{array}$ \\
\hline $\mathrm{A} 10^{28}$ & Zhang \& Ma (2020) & China & $\begin{array}{l}\text { Int J Environ } \\
\text { Res Public } \\
\text { Health }\end{array}$ & Transversal & $\begin{array}{c}\text { General population } \\
\qquad(n=400)\end{array}$ \\
\hline $\mathrm{A} 11^{29}$ & Tan et al. (2020) & China & $\begin{array}{l}\text { Brain, Behav } \\
\text { Immun }\end{array}$ & Transversal & $\begin{array}{c}\text { General population } \\
(n=1.323)\end{array}$ \\
\hline $\mathrm{A} 12^{30}$ & Özdin \& Özdin (2020) & Turkey & $\begin{array}{l}\text { Intl J Social } \\
\text { Psychiatry }\end{array}$ & Transversal & $\begin{array}{c}\text { General population } \\
\quad(n=343)\end{array}$ \\
\hline $\mathrm{A} 13^{31}$ & Zhang et al. (2020) & China & $\begin{array}{l}\text { Psychother } \\
\text { Psychosom }\end{array}$ & Transversal & $\begin{array}{c}\text { General population } \\
(n=2.182)\end{array}$ \\
\hline $\mathrm{A} 14^{32}$ & Huang et al. (2020) & China & $\begin{array}{l}\text { Chin J Indu } \\
\text { Hyg Occup Dis }\end{array}$ & Transversal & $\begin{array}{l}\text { Doctors and Nurses } \\
\qquad(\mathrm{n}=230)\end{array}$ \\
\hline $\mathrm{A} 15^{33}$ & $\begin{array}{l}\text { Ozamiz-Etxebarria } \\
\text { et al. (2020) }\end{array}$ & Spain & $\begin{array}{l}\text { Cad Saúde } \\
\text { Pública }\end{array}$ & Transversal & $\begin{array}{c}\text { General population } \\
(n=1.003)\end{array}$ \\
\hline $\mathrm{A} 16^{34}$ & Bo et al. (2020) & China & $\begin{array}{l}\text { Psychological } \\
\text { Medicine }\end{array}$ & Transversal & $\begin{array}{c}\text { General population } \\
(n=7.140)\end{array}$ \\
\hline $\mathrm{A} 17^{35}$ & Liu et al. (2020) & China & Psychiatry Res & Transversal & $\begin{array}{c}\text { General population } \\
(n=230)\end{array}$ \\
\hline $\mathrm{A} 18^{36}$ & Lu et al. (2020) & China & Psychiatry Res & Transversal & $\begin{array}{l}\text { Doctors and Nurses } \\
\quad(n=2.299)\end{array}$ \\
\hline $\mathrm{A} 19^{37}$ & Xiao et al. (2020) & China & Med Sci Monit & Transversal & $\begin{array}{c}\text { General population } \\
(n=170)\end{array}$ \\
\hline $\mathrm{A} 20^{38}$ & Zhang et al. (2020) & China & $\begin{array}{l}\text { Frontiers in } \\
\text { Psychiatry }\end{array}$ & Transversal & $\begin{array}{l}\text { Doctors and Nurses } \\
\qquad(n=1.523)\end{array}$ \\
\hline $\mathrm{A} 21^{39}$ & Roy et al. (2020) & India & $\begin{array}{l}\text { Asian J } \\
\text { Psychiatr }\end{array}$ & Transversal & $\begin{array}{c}\text { General population } \\
(n=662)\end{array}$ \\
\hline $\mathrm{A} 22^{40}$ & Hao et al. (2020) & China & Epilepsia & Case-control & $\begin{array}{c}\text { General population } \\
(n=504)\end{array}$ \\
\hline$A 23^{41}$ & Xiao et al. (2020) & China & Med Sci Monit & Transversal & $\begin{array}{l}\text { Doctors and Nurses } \\
\qquad(n=180)\end{array}$ \\
\hline $\mathrm{A} 24^{42}$ & Li et al. (2020) & China & $\begin{array}{l}\text { Int J Environ } \\
\text { Res Public } \\
\text { Health }\end{array}$ & Transversal & $\begin{array}{c}\text { General population } \\
\quad(n=17.865)\end{array}$ \\
\hline $\mathrm{A} 25^{43}$ & $\begin{array}{l}\text { Ahmad, Murad \& } \\
\text { Gardner (2020) }\end{array}$ & Iraq & $\begin{array}{l}\text { J Med Internet } \\
\text { Res }\end{array}$ & Transversal & $\begin{array}{c}\text { General population } \\
\quad(n=516)\end{array}$ \\
\hline A2644 & Cao et al. (2020) & China & Psychiatry Res & Transversal & $\begin{array}{c}\text { General population } \\
(n=7.143)\end{array}$ \\
\hline $\mathrm{A} 27^{45}$ & Li et al. (2020) & China & $\begin{array}{l}\text { Brain, Behav } \\
\text { Immun }\end{array}$ & Transversal & $\begin{array}{c}\text { General population } \\
(n=214) \\
\text { Nurses } \\
(n=526)\end{array}$ \\
\hline
\end{tabular}

Regarding the measurement of signs and symptoms of mental illness, 30 different psychometric instruments were used, with emphasis on the Impact of Event Scale-Revised (IES-R); $22,24,26-29,38$ Three studies used their own questionnaires, ${ }^{39,42-43}$ Table 3. 
Table 3 - Measurement instruments used in the studies included in the review ( $n=27)$. São Paulo, SP, Brazil. 2020.

\begin{tabular}{|c|c|}
\hline Utilized instruments & Reference \\
\hline 17-item self-reported PTSD Checklist (PCL-C) & $\mathrm{A} 16^{34}$ \\
\hline 7-item Generalized Anxiety Disorder (GAD-7) & $\mathrm{A} 6^{22}, \mathrm{~A} 7^{25}, \mathrm{~A} 9^{27}, \mathrm{~A} 20^{38}, \mathrm{~A} 26^{44}$ \\
\hline 7-item Insomnia Severity Index & $\mathrm{A} 6^{24}, \mathrm{~A} 9^{27}, \mathrm{~A} 11^{29}, \mathrm{~A} 13^{31}, \mathrm{~A} 20^{38}$ \\
\hline 9-item Patient Health Questionnaire & $\mathrm{A} 6^{24}, \mathrm{~A} 9^{27}, \mathrm{~A} 13^{31}, \mathrm{~A} 20^{38}$ \\
\hline Attachment Style Questionnaire (ASQ) & $\mathrm{A} 3^{21}$ \\
\hline $\begin{array}{l}\text { Center for Epidemiology Scale for Depression } \\
\text { (CES-D) }\end{array}$ & $A 7^{25}$ \\
\hline $\begin{array}{l}\text { Chinese version of Connor-Davidson resilience } \\
\text { scale (CD-RISC) }\end{array}$ & $\mathrm{A} 2^{20}$ \\
\hline Depression, Anxiety and Stress Scale (DASS-21) & $\mathrm{A} 1^{19}, \mathrm{~A} 4^{22}, \mathrm{~A} 8^{26}, \mathrm{~A} 11^{29}, \mathrm{~A} 15^{33}$ \\
\hline General Self-Efficacy Scale (GSES) & $\mathrm{A} 23^{41}$ \\
\hline Health Anxiety Inventory (HAI) & $\mathrm{A} 12^{30}$ \\
\hline Hospital Anxiety and Depression Scale (HADS) & $\mathrm{A} 12^{30}$ \\
\hline Impact of Event Scale-Revised (IES-R) & $\mathrm{A} 4^{22}, \mathrm{~A} 6^{24}, \mathrm{~A} 8^{26}, \mathrm{~A} 9^{27}, \mathrm{~A} 10^{28}, \mathrm{~A} 11^{29}, \mathrm{~A} 20^{38}$ \\
\hline $\begin{array}{l}\text { Italian Temperament Evaluation of Memphis, Pisa, } \\
\text { Paris and San Diego-Autoquestionnaire (TEMPS-A) }\end{array}$ & ( \\
\hline Kessler 10 Psychological Distress Scale (K10) & $\mathrm{A} 3^{21}$ \\
\hline Kessler 6-item psychological distress scale (K-6) & $\mathrm{A} 22^{40}$ \\
\hline Mental Health Lifestyle Scale (MHLSS) & $\mathrm{A} 10^{28}$ \\
\hline $\begin{array}{l}\text { Numeric rating scale (NRS) on fear, Hamilton } \\
\text { Anxiety Scale (HAMA) }\end{array}$ & $\mathrm{A} 18^{36}$ \\
\hline Hamilton Depression Scale (HAMD) & $\mathrm{A} 18^{36}$ \\
\hline Personal Social Capital Scale 16 (PSCl-16) & A1937 \\
\hline $\begin{array}{l}\text { Personality Inventory for DSM-5-Brief Form-Adult } \\
\text { (PID-5-BF) }\end{array}$ & $\mathrm{A} 1^{19}$ \\
\hline Pittsburgh Sleep Quality Index (PSQI) & $A 7^{25}$ \\
\hline Post-Traumatic Stress Disorder Self-rating Scale & $\mathrm{A} 14^{32}$ \\
\hline PTSD Checklist for DSM-5 (PCL-5) & $\mathrm{A} 17^{35}$ \\
\hline Self-rating Anxiety Acale (SAS) & $\mathrm{A} 14^{32}$ \\
\hline Sleep State Self-Rating Scale (SRSS) & $\mathrm{A} 5^{23}$ \\
\hline Social Support Rating Scale (SSRS) & $\mathrm{A} 2^{20}$ \\
\hline Spielberger State-Trait Anxiety Scale (STAI) & $\mathrm{A} 5^{23}$ \\
\hline Stanford Acute Stress Reaction (SASR) & $\mathrm{A} 19^{37}, \mathrm{~A} 23^{41}$ \\
\hline Symptom Check-List-90 (SCL-90) & $\mathrm{A} 2^{20}, \mathrm{~A} 13^{31}$ \\
\hline Vicarious Traumatization Questionnaire & $\mathrm{A} 27^{45}$ \\
\hline Own Questionnaire & $\mathrm{A} 21^{39}, \mathrm{~A} 24^{42}, \mathrm{~A} 25^{43}$ \\
\hline
\end{tabular}

The 27 studies identified 19 signs and symptoms of mental illness in the general population and in health professionals, the following stood out: anxiety (85\%), ${ }^{19-33,36-44}$ depression $(59 \%),{ }^{19-22,24}$ $-27.29-31.33 .26-28.40 .42$ stress (48\%), ${ }^{19-22.26-28.33 .37-38.40-41}$ insomnia $(33 \%)^{22-25,27,29,31,37-38,41}$ and Post Traumatic Stress Disorder (11\%). ${ }^{32,34-40}$ Being a woman, student, nurse and having previous physical symptoms or health problems, were significantly associated with greatest impacts on mental health. $24,26,30,32,35$ Figure 2 shows the frequency of the appearance of signs and symptoms according to the target population of the analyzed studies. 


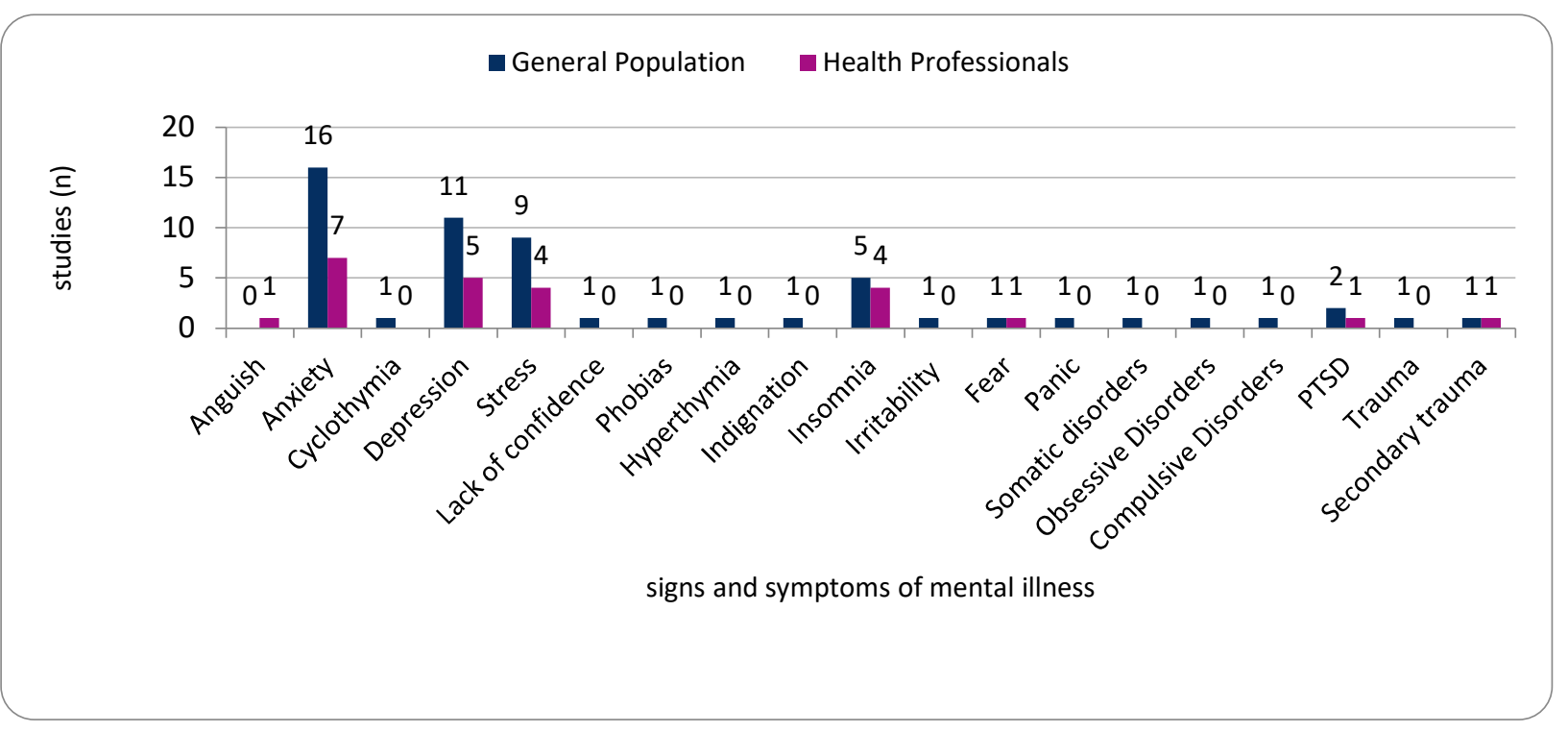

Figure 2 - Frequency of signs and symptoms of mental illness in the general population and in health professionals in the studies included in the review (n=27). São Paulo, SP, Brazil. 2020.

\section{Caption: PTSD = Post Traumatic Stress Disorder}

\section{DISCUSSION}

This review highlights the expressive interest of researchers and research centers in investigating the impacts generated on mental health due to the new Coronavirus pandemic, considering its abrupt and accelerated appearance. The selected studies provide important mental health indicators for the general population and health professionals impacted by the pandemic, constituting an essential basis for the formulation of strategic actions and the implementation of focal and community-based public policies.

Most studies measured the signs and symptoms of mental illness using validated psychometric scales, which provides rigor and greater control over the effectiveness of the clinical evaluations employed. ${ }^{19-38,40,44-45}$ Only three studies ${ }^{39,42-43}$ used their own questionnaires, which may indicate a specific scenario, as is typical in a pandemic. It should be noted that the Fear of Covid-19 Scale, ${ }^{46}$ for the Iranian population, and the Covid Stress Scales, ${ }^{47}$ for North Americans and Canadians, have both been validated, both with good psychometric properties. However, none of the studies included in this review used these references, probably because they were aimed at specific populations and cultures. Regarding this aspect, the need for alignment between coherence, relevance and the usefulness of the application of assessment instruments is indicated in view of the pandemic context, which is new and requires more accurate observation and analysis.

The fear of being infected and susceptibility to death, added to the speed of dissemination, the natural history and the course of the new disease, make the impacts on mental health evident, which calls for greater attention to interventions and the evaluation of results directed to coping with fear and its impacts. In the general population, the levels of anxiety and stress of healthy individuals become high and, on the other hand, potentiate the symptoms that already exist in people with previous mental disorders, increasing the risk of suicide..$^{5,48-50}$ In addition, the fear of the general population of being contaminated by the new Coronavirus and of becoming potential contaminants of family members was highlighted, compromising the health of the people who make up their affective network. ${ }^{22,26}$ In this sense, it is relevant to outline prevention and coping strategies regarding the factors that intensify 
fear, in order to act on their physiology, decrease anxiety levels and increase vigilance and protection against suicidal behavior.

Furthermore, factors such as fake news, difficulty in health insurance coverage to carry out and/or maintain treatment, adherence to compliance with quarantine/ social distancing /isolation measures, cause feelings of insecurity, hypervigilance and panic that affect psychological wellbeing. ${ }^{5,48-50}$ Thus, by understanding that the context of the Covid-19 pandemic brings a conjunctural phenomenon of social disorder and incorporates new phenomena that impact psychosocial well-being and interfere with mental health, it is essential to raise these factors in each context and/or territory, making it possible to register previous or consequent conditions and, therefore, to design resolute interventions, capable of responding to the situation both immediately and in the long term, in this scope and in a post-pandemic character.

An online study, conducted during the initial stage of the pandemic with 1,210 individuals from 194 cities in China, revealed that $53.8 \%$ rated the psychological impact of the disease as moderate or severe, of which $28.8 \%, 16.5 \%$ and $8.1 \%$ reported moderate or severe symptoms of anxiety, depression and stress, respectively. ${ }^{31}$ Others also had similar results ${ }^{19,21-23,25,28-31,33,37-39,42-43}$ when showing irritability, insecurity, ${ }^{21}$ insomnia, ${ }^{23,25,29,31,37}$ somatic, compulsive symptoms, phobias, ${ }^{31}$ fear ${ }^{39}$ and panic. ${ }^{43}$

When analyzing the content of posts on social networks related to Covid-19, a Chinese study with 17,865 users identified significant reports of anxiety, depression and feelings of indignation and dissatisfaction. ${ }^{42}$ Based on this evidence, the advent of possibilities of health interventions based on web browsing, which can prove to be an effective strategy in times when confinement is prevalent. As previously stated, being a woman, student and having previous physical symptoms or health problems are aspects that were significantly associated with higher levels of anxiety, depression and stress. ${ }^{26,30}$ Based on this evidence, it is essential to further investigate and interventions that consider markers such as sex and, in particular, gender, in order to recognize the specificities of femininities, masculinities and non-binary identities present in the manifestations of disorders that affect mental health, as well as responses and/or coping strategies employed by women and men in pandemic settings.

Another study with 7,143 individuals indicated that $0.9 \%, 2.7 \%$ and $21.3 \%$ experienced severe, moderate and mild anxiety, respectively. Having infected relatives or acquaintances is a risk factor for increased anxiety, as well as living in urban areas or with parents and having family income stability are protective factors to raise anxiety levels. ${ }^{44}$ Although these data are preliminary and express the course of the disease in its initial period, especially in countries on the Asian continent, and, therefore, are not yet consolidated, they are already presented as a relevant finding to be considered as actions that protect mental health through the impacts caused by Covid-19.

The conditions previously raised are more prevalent in people subjected to quarantine due to psychological distress in these circumstances, ${ }^{48}$ since, in the pandemic context, uncertainty potentiates dysphoric and imaginary mental states regarding the possibility of contamination of oneself, others and death. In view of this evidence, it is recommended to direct care to the processes of psychological distress, panic attacks and mourning.

Another phenomenon identified, which needs to be considered, is the stigmatization of which individuals considered to be suspected or confirmed cases of Covid-19 have been the target. ${ }^{5,51-52}$ Therefore, it is necessary to use instruments that can assess and/or measure the elements present in the stigma and its impact on the subjects mental health, especially in the case of Covid-19, so that it is possible to develop a more consolidated framework about the stigmatizing process in this scenario.

Furthermore, unexpected changes in family dynamics, such as closing schools, companies and public places and limiting or even prohibiting physical and leisure activities, changes in routines 
and work, such as "home office" , and detachment cause both the general population and health professionals to have feelings of helplessness, abandonment and insecurity due to the economic and social repercussions caused by the pandemic. ${ }^{5}$ In this sense, considering the multiple impacts of an intrapersonal and also interpersonal nature on mental health, it is important to perform public civil actions to confront the impacts and negative repercussions caused by the pandemic, in the quest to strengthen intersectoriality and social and health interprofessionality, for the programmatic establishment of investments in this field.

In terms of the impacts on mental health of health professionals, nurses and doctors, acting on the frontline of care are the most representative professional categories in the selected publications, and present expressive reports of psychological distress. ${ }^{20,24,27,32,36,38,41,45}$

A study of 1,257 doctors and nurses, active and non-active on the front line, revealed a considerable proportion of symptoms of depression (50.4\%), anxiety (44.6\%), insomnia (34.0\%) and distress ( 71.5\%). ${ }^{24}$ Another study, with 230 doctors and nurses, showed an incidence of anxiety of $23.04 \%$, classified between severe $(2.17 \%)$ and moderate $(4.78 \%)$. Frontline nurses reported more severe degrees of these symptoms..$^{24,32}$ In view of these findings, there is an urgent need to promote actions in services in which health professionals work, especially nursing professionals, as they make up a large percentage of health professionals, such as how to provide strategic interventions that focus on coping with mental health problems.

It is also worth highlighting the current concern with maintaining personal and professional integrity, maintaining life and reducing potential lost years and a gap in health coverage, especially in Nursing, due to the high number of deaths, illnesses and disabilities of professionals caused by Covid-19, which should imply an emergency global action to protect the health worker category in their work process, considering, especially, the maintenance of mental health.

The work process of nursing professionals is permeated by specificities that prolong the length of stay in health services and put them in direct contact with stressful and complex elements of care. In the context of the pandemic, factors such as inadequate conditions, excessive workload, reduced amount of personal protective equipment and lack of specific skills generate feelings of fear, anxiety and helplessness, leading these professionals to face more severe changes in their daily lives, which compromise their psychological well-being and mental health, resulting in physical and mental exhaustion. ${ }^{53-55}$

Still on this aspect, it is relevant to consider that, because they deal directly with patients affected by Covid-19, these professionals may suffer more significantly from the stigma than the general population, especially in the places where they live, implying the need to operationalize awareness and education strategies among the population and psycho-emotional support for these individuals in coping with stigma. ${ }^{5}$

It is noteworthy that some professionals, despite not working on the front line, are liable to present psychological suffering and may experience the phenomenon of "secondary traumatization", from which although the person does not directly suffer a trauma (for example, experiencing a disaster or a cruel situation), but is affected and starts to show psychological symptoms resulting from empathy for the victims of a specific event. A study of 234 nurses who worked on the front line and 292 nurses who did not, revealed that those who did not work on the front line had higher levels of secondary trauma compared to the nurses who did..$^{45}$ Thus, is essential to expand the offer of care technologies that establish positive interventions to promote psychosocial well-being focused on coping with secondary trauma.

Related to other epidemics, studies suggest that impacts on mental health can be long lasting and remain. ${ }^{7,9}$ A study of 7,140 clinically stable Covid-19 patients found that $96 \%$ developed Posttraumatic Stress Disorder, ${ }^{34}$ another study showed that the prevalence of this disorder, one month 
after the epidemic, in the most affected areas in China, was 7\%, higher in women and in patients who reported irregular sleep due to the pandemic. ${ }^{35}$ Health professionals $(n=230)$, especially women $(44.30 \%)$ also presented high rates of Posttraumatic Stress Disorder (42.92\%).

Although the majority of studies were carried out in China, it is worth considering that the disease has spread to different continents, affecting countries in which health systems and work processes are different, with different ways of coping, but, even so, it implies decision making and global strategic action for greater involvements in the health workforce.

The devastating scenario of this pandemic has a real and negative impact on contemporaneity, given the potential years lost by the health professional categories and the general population, which indicates a damaging deficit of health professionals, especially nurses, throughout the world, thereby compromising global health coverage on different continents. Thus, the results of this review highlight the possibility of implementing effective actions to minimize the effects of mental illness in the affected countries.

The fact that the search strategy was limited to a single term to characterize mental illness is considered a study limitation, this choice is justified by making the strategy more comprehensive.

\section{CONCLUSION}

The Covid-19 pandemic is causing mental illness in the general population and in health professionals, with particular reference to anxiety, depression, stress and Post-Traumatic Stress Disorder. Women, students and professional nurses are among the most affected.

While the curves of the new Coronavirus SARS-CoV-2 infection indicators are decreasing worldwide, the consequences related to mental health persist and can cause harmful effects in the long term, resulting in the need for urgent and necessary individual and community-wide strategic actions that minimize the occurrence of emotional deteriorations and psychological problems in the population and in health teams, as these cannot be neglected. 


\section{REFERENCES}

1. Li Q, Med M, Guan X, Wu P, Wang X, Zhou L, et al. Early transmission dynamics in Wuhan, China, of novel coronavirus-infected pneumonia. N Engl J Med [Internet]. 2020 [cited 2020 May 19];382:1199-1207. Available from: https://dx.doi.org/10.1056/nejmoa2001316

2. World Health Organization Statement on the second meeting of the international health regulations (2005) Emergency Committee regarding the outbreak of novel coronavirus (2019-nCoV). Published January 30, 2020 [cited 2020 May 19]. Available from: https://www.who.int/news-room/ detail/30-01-2020-statement-on-the-second-meeting-of-the-international-health-regulations(2005)-emergency-committee-regarding-the-outbreak-of-novel-coronavirus-(2019-ncov)

3. Chen N, Zhou M, Dong X, Qu J, Gong F, Han Y, et al. Epidemiological and clinical characteristics of 99 cases of 2019 novel coronavirus pneumonia in Wuhan, China: a descriptive study. Lancet [Internet]. 2020 [cited 2020 May 19];395(10223):507-13. Available from: https://dx.doi.org/10.1016/ S0140-6736(20)30211-7

4. Devaux CA, Rolain JM, Colson P, Raoult D. New insights on the antiviral effects of chloroquine against coronavirus: what to expect for COVID-19? Int J Antimicrob Agents [Internet]. 2020 [cited 2020 May 19];55(5):105938. Available from: https://dx.doi.org/10.1016/j.ijantimicag.2020.105938

5. Ornell F, Schuch JB, Sordi AO, Kessler FHP. Pandemic fear" and COVID-19: mental health burden and strategies. Braz J Psychiatry [Internet]. 2020 [cited 2020 May 25];42(3):232-5. Available from: https://dx.doi.org/10.1590/1516-4446-2020-0008

6. Hughes F, Grigg M, Fritsch K, Calder S. Psychosocial response in emergency situations--the nurse's role. Int Nurs Rev [Internet]. 2007 [cited 2020 May 25];54(1):19-27. Available from: https:// dx.doi.org/10.1111/j.1466-7657.2007.00514.x

7. Xiang YT, Yang Y, Li W, Zhang L, Zhang Q, Cheung T, et al. Timely mental health care for the 2019 novel coronavirus outbreak is urgently needed. Lancet Psychiatry [Internet]. 2020 [cited 2020 May 25];7(3):228-9. Available from: https://dx.doi.org/10.1016/S2215-0366(20)30046-8

8. Son H, Lee WJ, Kim HS, Lee KS, You M. Examination of hospital workers emotional responses to an infectious disease outbreak: lessons from the 2015 MERS Co-V outbreak in South Korea. Disaster Med Public Health Prep [Internet]. 2019 [cited 2020 May 25];13: 504-10. Available from: https://dx.doi.org/10.1017/dmp.2018.95

9. Seon-Cheol P, Yong CP. Mental health care measures in response to the 2019 novel coronavirus outbreak in Korea. Psychiatry Investig [Internet]. 2020 [cited 2020 May 25];17(2):85-6. Available from: https://dx.doi.org/10.30773/pi.2020.0058

10. Xiang YT, Yang Y, Li W, Zhang L, Zhang Q, Cheung T, et al. Timely mental health care for the 2019 novel coronavirus outbreak is urgently needed. Lancet Psychiatry [Internet]. 2020 [cited 2020 May 25];7(3):228-9. Available from: https://dx.doi.org/10.1016/S2215-0366(20)30046-8

11. Jeong H, Yim HW, Song YJ, Ki M, Min JA, et al. Mental health status of people isolated due to middle east respiratory syndrome. Epidemiol Health [Internet]. 2016 [cited 2020 May 25];5(38):e2016048. Available from: https://dx.doi.org/10.4178/epih.e2016048

12. Lee SM, Kang WS, Cho AR, Kim T, Park JK. Psychological impact of the 2015 MERS outbreak on hospital workers and quarantined hemodialysis patients. Compr Psychiatry [Internet]. 2018 [cited 2020 May 25];87:123-7. Available from: https://dx.doi.org/10.1016/j.comppsych.2018.10.003

13. Khalid I, Khalid TJ, Qabajap MR. Barnard AG, Qushmaq IA. Healthcare workers emotions, perceived stressors and coping strategies during a MERS-CoV outbreak. Clin Med Res [Internet]. 2016 [cited 2020 May 25];14(1):7-14. Available from: https://dx.doi.org/10.3121/cmr.2016.1303 
14. Ji-Seon P, Eun-Hyun L, No-Rye P, Young HC. Mental health of nurses working at a governmentdesignated hospital during a MERS-CoV outbreak: a cross-sectional study. Arch Psychiatr Nurs [Internet]. 2018 [cited 2020 May 25];32(1):2-6. Available from: https://dx.doi.org/10.1016/j. apnu.2017.09.006

15. Peters MDJ, Godfrey C, McInerney P, Munn Z, Tricco AC, Khalil, H. Chapter 11: Scoping Reviews. In: Aromataris E, Munn Z, Editors. JBI Reviewer's Manual, JBI (2020 version) [Internet]. 2020 [cited 2020 May 07]. Available from: https://dx.doi.org/10.46658/jbirm-20-01

16. Tricco AC, Lillie E, Zarin W, O'Brien KK, Colquhoun H, Levac D, et al. PRISMA extension for scoping reviews (PRISMA-ScR): checklist and explanation. Ann Intern Med [Internet]. 2018 [cited 2020 Mar 29];169(7):467-73. Available from: https://dx.doi.org/10.7326/M18-0850

17. Ursi ES, Galvão CM. Perioperative prevention of skin injury: an integrative literature review. Rev Latino-Am Enfermagem [Internet]. 2006 [cited 2020 May 07];14(1):124-31. Available from: http:// www.scielo.br/pdf/rlae/v14n1/v14n1a17.pdf

18. Munn Z, Peters MDJ, Stern C, Tufanaru C, McArthur A, Aromataris E. Systematic review or scoping review? guidance for authors when choosing between a systematic or scoping review approach. BMC Med Res Methodol [Internet]. 2018 [cited 2020 May 07]; 8(1):143. Available from: https://dx.doi.org/10.1186/s12874-018-0611-x

19. Mazza C, Ricci E, Biondi S, Colasanti M, Ferracuti S, Napoli C, et al. A nationwide survey of psychological distress among Italian people during the COVID-19 pandemic: immediate psychological responses and associated factors. Int J Environ Res Public Health [Internet]. 2020 [cited 2020 May 07];17(9):3165. Available from: https://dx.doi.org/10.3390/ijerph17093165

20. Cai W, Lian B, Song X, Hou T, Deng G, Li H. A cross-sectional study on mental health among health care workers during the outbreak of Corona Virus Disease 2019. Asian J Psychiatr [Internet]. 2020 [cited 2020 May 07];24(51):102111. Available from: https://dx.doi.org/10.1016/j. ajp.2020.102111

21. Moccia L, Janiri D, Pepe M, Dattoli L, Molinaro M, De Martin V, et al. Affective temperament, attachment style, and the psychological impact of the COVID-19 outbreak: an early report on the Italian general population. Brain Behav Immun [Internet]. 2020 [cited 2020 May 07];20(20):305869. Available from: https://dx.doi.org/10.1016/j.bbi.2020.04.048

22. Wang $C$, Pan $R$, Wan $X$, Tan $Y, X u L$, et al. A longitudinal study on the mental health of general population during the COVID-19 epidemic in China. Brain Behav Immun [Internet]. 2020 [cited 2020 May 07];87:40-8. Available from: https://dx.doi.org/10.1016/j.bbi.2020.04.028

23. Liu K, Chen $\mathrm{Y}, \mathrm{Wu} \mathrm{D}$, Lin R, Wang Z, Pan L. Effects of progressive muscle relaxation on anxiety and sleep quality in patients with COVID-19. Complement Ther Clin Pract [Internet]. 2020 [cited 2020 May 07];39:101132. Available from: https://dx.doi.org/10.1016/j.ctcp.2020.101132

24. Lai J, Ma S, Wang Y, Cai Z, Hu J, Wei N. Factors associated with mental health outcomes among health care workers exposed to coronavirus disease 2019. JAMA Netw Open [Internet]. 2020 [cited 2020 May 07]; 3(3):e203976. Available from: https://dx.doi.org/10.1001/jamanetworkopen.2020.3976

25. Huang Y, Zhao N. Generalized anxiety disorder, depressive symptoms and sleep quality during COVID-19 outbreak in China: a web-based cross-sectional survey. Psychiatry Res [Internet]. 2020 [cited 2020 May 07];12(288):112954. Available from: https://dx.doi.org/10.1016/j. psychres.2020.112954

26. Wang C, Pan R, Wan X, Tan Y, Xu L, Ho CS, et al. Immediate psychological responses and associated factors during the initial stage of the 2019 coronavirus disease (COVID-19) epidemic among the general population in China. Int J Environ Res Public Health [Internet]. 2020 [cited 2020 May 07];17(5):e1729. Available from: https://dx.doi.org/10.3390/ijerph17051729 
27. Kang L, Ma S, Chen M, Yang J, Wang Y, Li R, et al. Impact on mental health and perceptions of psychological care among medical and nursing staff in Wuhan during the 2019 novel coronavirus disease outbreak: A cross-sectional study. Brain Behav Immun [Internet]. 2020 [cited 2020 May 07];87:11-7. Available from: https://dx.doi.org/10.1016/j.bbi.2020.03.028

28. Zhang Y, Ma ZF. Impact of the COVID-19 pandemic on mental health and quality of life among local residents in Liaoning Province, China: a cross-sectional study. Int J Environ Res Public Health [Internet]. 2020 [cited 2020 May 07];17(7):e2381. Available from: https://dx.doi.org/10.3390/ ijerph17072381

29. Tan W, Hao F, Mclntyre RS, Jiang L, Jiang X, Zhang L, et al. Is Returning to work during the COVID-19 pandemic stressful? a study on immediate mental health status and psychoneuro immunity prevention measures of Chinese workforce. Brain Behav Immun [Internet]. 2020 [cited 2020 May 07];87:84-92. Available from: https://dx.doi.org/10.1016/j.bbi.2020.04.055

30. Özdin S, Özdin ŞB. Levels and predictors of anxiety, depression and health anxiety during COVID-19 pandemic in Turkish society: The importance of gender. Int J Soc Psychiatry [Internet]. 2020 [cited 2020 May 07];66(5):504-11. Available from: https://dx.doi.org/10.1177/0020764020927051

31. Zhang WR, Wang K, Yin L, Zhao WF, Xue Q, Peng M, et al. Mental health and psychosocial problems of medical health workers during the COVID-19 epidemic in China. Psychother Psychosom [Internet]. 2020 [cited 2020 May 07];89:242-50. Available from: https://dx.doi. org/10.1159/000507639

32. Huang JZ, Han MF, Luo TD, Ren AK, Zhou XP. Mental health survey of 230 medical staff in a tertiary infectious disease hospital for COVID-19. Zhonghua Lao Dong Wei Sheng Zhi Ye Bing Za Zhi [Internet]. 2020 [cited 2020 May 07];38(3):192-5. Available from: https://dx.doi.org/10.3760/ cma.j.cn121094-20200219-00063

33. Ozamiz-Etxebarria N, Dosil-Santamaria M, Picaza-Gorrochategui M, Idoiaga-Mondragon N. Stress, anxiety, and depression levels in the initial stage of the COVID-19 outbreak in a population sample in the northern Spain. Cad Saúde Publica [Internet]. 2020 [cited 2020 May 07];36(4):e00054020. Available from: https://dx.doi.org/10.1590/0102-311X00054020

34. Bo HX, Li W, Yang Y, Wang Y, Zhang Q, Cheung T, et al. Posttraumatic stress symptoms and attitude toward crisis mental health services among clinically stable patients with COVID-19 in China. Psychol Med [Internet]. 2020 [cited 2020 May 07]. Available from: https://dx.doi.org/10.1017/ S0033291720000999

35. Liu N, Zhang F, Wei C, Jia Y, Shang Z, Sun L, et al. Prevalence and predictors of PTSS during COVID-19 outbreak in China hardest-hit areas: gender differences matter. Psychiatry Res [Internet]. 2020 [cited 2020 May 07];287:112921. Available from: https://dx.doi.org/10.1016/j. psychres.2020.112921

36. Lu W, Wang H, Lin Y, Li L. Psychological status of medical workforce during the COVID-19 pandemic: A cross-sectional study. Psychiatry Res [Internet]. 2020 [cited 2020 May 07]; 288:112936. Available from: https://dx.doi.org/10.1016/j.psychres.2020.112936

37. Xiao H, Zhang Y, Kong D, Li S, Yang N. Social capital and sleep quality in individuals who selfisolated for 14 days during the coronavirus disease 2019 (COVID-19) outbreak in january 2020 in China. Med Sci Monit [Internet]. 2020 [cited 2020 May 07];26: e923921. Available from: https:// dx.doi.org/10.12659/MSM.923921

38. Zhang C, Yang L, Liu S, Ma S, Wang Y, Cai Z, et al. Survey of insomnia and related social psychological factors among medical staff involved in the 2019 novel coronavirus disease outbreak. Front Psychiatry [Internet]. 2020 [cited 2020 May 07];11:306. Available from: https:// dx.doi.org/10.3389/fpsyt.2020.00306 
39. Roy D, Tripathy S, Kar SK, Sharma N, Verma SK, Kaushal V. Study of knowledge, attitude, anxiety \& perceived mental healthcare need in Indian population during COVID-19 pandemic. Asian J Psychiatr [Internet]. 2020 [cited 2020 May 07];51:102083. Available from: https://dx.doi. org/10.1016/j.ajp.2020.102083

40. Hao X, Zhou D, Li Z, Zeng G, Hao N, Li E, et al. Severe psychological distress among epilepsy patients during the COVID-19 outbreak in southwest China. Epilepsia [Internet]. 2020 [cited 2020 May 07];61(6):1166-73. Available from: https://dx.doi.org/https://doi.org/10.1111/epi.16544

41. Xiao H, Zhang Y, Kong D, Li S, Yang N. The effects of social support on sleep quality of medical staff treating patients with coronavirus disease 2019 (COVID-19) in january and february 2020 in China. Med Sci Monit [Internet]. 2020 [cited 2020 May 07];26:e923549. Available from: https:// dx.doi.org/10.12659/MSM.923549

42. Li S, Wang Y, Xue J, Zhao N, Zhu T. The impact of COVID-19 epidemic declaration on psychological consequences: a study on active weibo users. Int J Environ Res Public Health [Internet]. 2020 [cited 2020 May 07];17(6):e2032. Available from: https://dx.doi.org/10.3390/ijerph17062032

43. Ahmad AR, Murad HR, Gardner M. The impact of social media on hyped panic during the COVID-19 pandemic: the Iraqi Kurdistan case. J Med Internet Res [Internet]. 2020 [cited 2020 May 07]; 22(5):e19556. Available from: https://dx.doi.org/10.2196/19556

44. Cao W, Fang Z, Hou G, Han M, Xu X, et al. The psychological impact of the COVID-19 epidemic on college students in China. Psychiatry Res [Internet]. 2020 [cited 2020 May 07];287:112934. Available from: https://dx.doi.org/10.1016/j.psychres.2020.112934

45. Li Z, Ge J, Yang M, Feng J, Qiao M, Jiang R, et al. Vicarious traumatization in the general public, members, and non-members of medical teams aiding in COVID-19 control. Brain Behav Immun [Internet]. 2020 [cited 2020 May 07]; pii: S0889-1591(20)30309-3. Available from: https://dx.doi. org/10.1016/j.bbi.2020.03.007

46. Ahorsu DK, Lin CY, Imani V, Saffari M, Griffiths MD, Pakpou AH. The fear of COVID-19 scale: development and initial validation. Int J Ment Health Addict [Internet]. 2020 [cited 2020 May 07]; 27:1-9. Available from: https://dx.doi.org/10.1007/s11469-020-00270-8

47. Taylor S, Landry C, Paluszek M, Fergus TA, Mckay D, Asmundson GJG. Development and initial validation of the COVID stress scales. J Anxiety Disord [Internet]. 2020 [cited 2020 May 07];72:102232. Available from: https://dx.doi.org/10.1016/j.janxdis.2020.102232

48. Asmundson GJG, Taylor S. Coronaphobia: fear and the 2019nCoV outbreak. J Anxiety Disord [Internet]. 2020 [cited 2020 May 07];70:102196. Available from: https://dx.doi.org/10.1016/j. janxdis.2020.102196

49. Carvalho PMM, Moreira MM, Oliveira MNA, Landim JMM, Rolim Neto ML. The psychiatric impact of the novel coronavirus outbreak. Psychiatry Res [Internet]. 2020 [cited 2020 May 07]; 286:112902. Available from: https://dx.doi.org/10.1016/j.psychres.2020.112902

50. Brooks SK, Webster RK, Smith LE, Woodland L, Wessely S, Greenberg N, et al. The psychological impact of quarantine and how to reduce it: a quick review of the evidence. Lancet [Internet]. 2020 [cited 2020 May 07];395:912-20. Available from: https://dx.doi.org/10.1016/S0140-6736(20)30460-8

51. Shigemura J, Ursano RJ, Morganstein JC, Kurosawa M, Benedek DM. Public responses to the new coronavirus 2019 (2019-nCoV) in Japan: consequences for mental health and target populations. Psychiatry Clin Neurosci [Internet]. 2020 [cited 2020 May 07];74(4):281-2. Available from: https://dx.doi.org/10.1111/pcn.12988

52. Mohammed AM, Mark DG. First COVID-19 suicide case in Bangladesh due to fear of COVID-19 and xenophobia: possible suicide prevention strategies. Asian J Psychiatr [Internet]. 2020 [cited 2020 May 07];51:102073. Available from: https://dx.doi.org/10.1016/j.ajp.2020.102073 
53. Fernandes MA, Ribeiro AAA. Salud mental y estrés ocupacional en trabajadores de la salud a la primera línea de la pandemia de COVID-19. Rev Cuidarte [Internet]. 2020 [cited 2020 May 07];11(2):e1222. Available from: https://dx.doi.org/10.15649/cuidarte.1222

54. Gold JA. Covid-19: adverse mental health outcomes for healthcare workers. BMJ [Internet]. 2020 [cited 2020 May 07];369:m1815. Available from: https://dx.doi.org/10.1136/bmj.m1815

55. Silva DAR, Pimentel RFW, Merces MC. Covid-19 and the pandemic of fear: reflections on mental health. Rev Saúde Pública [Internet]. 2020 [cited 2020 May 07];54:e46. Available from: https:// dx.doi.org/10.11606/s1518-8787.2020054002486 


\section{NOTES}

\section{CONTRIBUTION OF AUTHORITY}

Study design: Moreira WC.

Data collect: Moreira WC, Sousa AR, Nóbrega MPSS.

Data analysis and interpretation: Moreira WC, Sousa AR.

Discussion of results: Moreira WC, Sousa AR.

Writing and / or critical review of the content: Moreira WC, Sousa AR, Nóbrega MPSS.

Final review and approval of the final version: Moreira WC, Sousa AR, Nóbrega MPSS.

\section{FUNDING INFORMATION}

National Council for Scientific and Technological Development - CNPq, Ministry of Science, Technology, Innovation and Communications, Ministry of Health of Brazil - MoH. Call MCTIC/CNPq/FNDCT/MS/ SCTIE/Decit No 07/2020 - Research to cope with COVID-19, its consequences and other severe acute respiratory syndromes. Project $n^{\circ} 4011002020$.

\section{CONFLICT OF INTEREST}

There is no conflict of interest.

\section{EDITORS}

Associated Editors: Ana Izabel Jatobá de Souza, Gisele Cristina Manfrini Fernandes, Mara Ambrosina de Oliveira Vargas

Editor-in-chief: Roberta Costa

\section{HISTORICAL}

Received: May 27, 2020.

Approved: July 01, 2020.

\section{CORRESPONDING AUTHOR}

Wanderson Carneiro Moreira wanderson.moreira@usp.br 